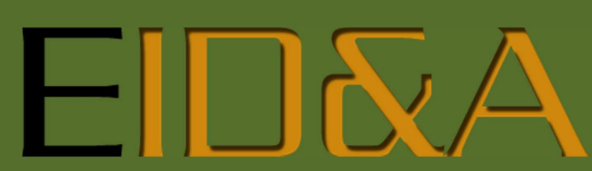

Revista Eletrônica de Estudos Integrados em Discurso e Argumentação

dx.doi.org/10.17648/eidea-16-2215

\title{
POLÍTICA, MÍDIA E FALA POPULAR. UM PORTA-VOZ DO POVO NA IMPRENSA BRASILEIRA ${ }^{\mathrm{i}}$
}

Carlos Piovezani ${ }^{\text {ii }}$

Resumo: $\mathrm{O}$ artigo pretende responder às seguintes questões, com base na Análise do discurso: o que se diz na mídia brasileira sobre as falas públicas de Lula como candidato, presidente e ex-presidente? De que modo se formulam esses enunciados midiáticos? Quais são suas relações com dizeres antigos e modernos que depreciam a fala popular? Há variações ou não no tratamento dispensado pela mídia à fala pública de Lula, na medida em que seus veículos são conservadores ou progressistas? Quais são as relações entre a depreciação da fala pública popular e os estigmas atribuídos à escuta popular da fala pública? Para fazê-lo, analisamos uma série de enunciados extraídos de um corpus constituído por textos dos jornais Folha de São Paulo e 0 Estado de São Paulo e das revistas Veja e Época, publicados desde 1989 até nossos dias.

Palavras-chave: Discurso. Fala pública. Mídia. Política.

\begin{abstract}
The article intends to answer the following questions, based on Discourse Analysis: what is said in the Brazilian media in regard to Lula's public speeches as candidate, president and former president? How are these media enunciations stated? What relations do they establish with old and modern statements that belittle popular speech? Are there variations in the approach to Lula's public speech as the media vehicles present conservative or progressive tendencies? What are the relations between the depreciation of popular public speech and the stigma conferred to the popular listening of public speeches? In order to do so, we analyze a series of statements extracted from a corpus composed of texts from the newspapers Folha de São Paulo and O Estado de São Paulo and from the magazines Veja and Época, published between 1989 and the present days.
\end{abstract}

Keywords: Discourse. Public Speeaking. Media. Politics.

\footnotetext{
'Este texto apresenta resultados da pesquisa "A língua, o corpo e a voz do povo: uma análise dos discursos da mídia sobre a fala pública eleitoral de Lula", financiada pela FAPESP (Processo 2016/04024-0) e desenvolvida na École des Hautes Études en Sciences Sociales (EHESS/Paris). O prosseguimento desse estudo ocorreu na Unicamp, com o financiamento do CNPq (Processo 104634/2016-2).

ii Docente do Programa de Pós-Graduação em Linguística da Universidade Federal de São Carlos (UFSCar), Brasil. Bolsista de produtividade do CNPq. E-mail: cpiovezani@uol.com.br.
} 
EID\&A - Revista Eletrônica de Estudos Integrados em Discurso e Argumentação, Ilhéus, n. 16 esp. "Discurso e argumentação na política latino-americana, set.2018.

\section{Introdução}

Em suas noites, operários falam e escrevem para protestar contra as explorações sofridas, para buscar alguma libertação e para combater esta "dupla e irremediável exclusão":

Para que o protesto das oficinas tenha voz, para que a emancipação operária tenha uma face a mostrar, para que os proletários existam como sujeitos de um discurso coletivo que dê sentido à multiplicidade de seus agrupamentos e de suas lutas, é preciso que essas pessoas já se tenham transformado em outras, na dupla e irremediável exclusão de viver como operários e falar como burgueses. (RANCIÈRE, 1988, p. 11).

Sem dúvida, as dores sentidas pelos que, lançados e mantidos à mercê dos abusos econômicos, da marginalidade política, da indignidade social e das carências subjetivas, continuarão a falar a linguagem da gente pobre e humilhada serão ainda mais intensas e seus efeitos ainda mais nefastos. Não é menos verdade, porém, que, em sociedades injustas e desiguais, mesmo os raros sujeitos que conseguem melhores condições materiais de vida, mas não alcançam a proeza de apagar completamente as marcas de sua origem de classe, têm seus recursos e formas de expressão desdenhados e atacados por aqueles que buscam perpetuar opressões e dominações. Na reprodução das relações de força, as discriminações culturais, simbólicas e linguísticas que as classes dominantes infligem aos que elas mesmas jogam e conservam na miséria cumprem uma função decisiva. A manutenção, a força e o alcance ideológico dessas discriminações se servem de esquemas e mecanismos criados e alimentados consciente e inconscientemente por aqueles que propõem distinções que os tornam ainda mais distintos. Para tanto, seus discursos se assentam em processos, simulacros e efeitos que, bem consolidados no pensamento ocidental, prestam contribuições fundamentais aos gestos que pretendem rebaixar rebaixados e eleger eleitos.

À medida que são forjadas, dispostas e bem assentadas, as oposições entre natureza/cultura, corpo/alma e barbárie/civilização, mas também entre oralidade/escrita, voz/fala, erro gramatical/correção linguística, estabelecem frequentemente hierarquias e valores que consagram uns poucos e estigmatizam amplas maiorias. Se essas divisões podem contribuir para a organização cognitiva do mundo, certamente fundamentam a reprodução de relações de dominação. Em De Certeau (2002, p.211-242), apreendemos o funcionamento de um mecanismo que pode ser assim estendido: as descrições e os julgamentos "burgueses" sobre os desempenhos orais 
EID\&A - Revista Eletrônica de Estudos Integrados em Discurso e Argumentação, Ilhéus, n. 16 esp. "Discurso e argumentação na política latino-americana, set.2018.

"proletários" são frequentemente escritos e reiteram o esquema profundamente ancorado em práticas e no imaginário cotidiano: "metrópole civilizada" versus "colônia selvagem" etc. Assim, as distinções entre as modalidades linguísticas da oralidade e da escrita e as oposições voz (animal) e linguagem (humana) cumprem um importante papel nessas separações e hierarquias, incidem sobre elas e ainda recebem seus influxos. Sem maiores dificuldades, é possível conceber a extensão desse funcionamento a outras divisões e economias nas relações de força entre elites e classes populares, homens e mulheres, brancos e negros/indígenas, normais e loucos, heterossexuais e homossexuais, adultos e crianças etc. Além de vantagens econômicas, políticas e sociais, os primeiros integrantes de cada um desses pares usufruem frequentemente o privilégio da "razão gráfica", mediante a qual julgam e classificam as vidas e as vozes dos últimos.

No Brasil de nossos tempos, a mídia de grande circulação funda-se ainda nessas oposições e consolida esse mecanismo, quando se trata de descrever e avaliar as performances de linguagem dos sujeitos pertencentes às classes populares ou que delas sejam oriundos. Com efeito, podemos identificar em jornais e revistas brasileiras discursos que tematizam de modo central ou secundário os diversos usos da língua, do corpo e da voz como marcas das diferentes classes e grupos sociais. Provenientes de tais discursos, encontramse particularmente descrições, comentários e avaliações sobre as variedades linguísticas, sobre formas e posturas corporais e sobre características fonéticas e prosódicas do que se concebe como a fala popular. Com base nessa constatação, pretendemos apresentar aqui resultados de uma análise de discursos da mídia sobre a fala pública do ex-presidente Luiz Inácio Lula da Silva, considerando o fato de que não raras vezes se estabelecem relações de identidade ou de proximidade entre seus empregos do verbo, do corpo e da voz e aqueles dos sujeitos que pertencem às classes populares.

Em outros termos, neste artigo, nós nos propomos a responder às seguintes questões: o que se diz na mídia brasileira dos usos linguísticos, corporais e vocais de Lula em suas práticas de fala pública? Como se formulam esses enunciados midiáticos? De que domínios eles provêm? Quais são suas relações com dizeres antigos e modernos que depreciam a fala popular? Há variações ou não no tratamento dispensado pela mídia à fala pública de Lula, na medida em que seus veículos são conservadores ou progressistas? Quais são as relações entre a depreciação da fala pública popular e os estigmas 
EID\&A - Revista Eletrônica de Estudos Integrados em Discurso e Argumentação, Ilhéus, n. 16 esp. "Discurso e argumentação na política latino-americana, set.2018.

atribuídos à escuta popular da fala pública? Para que pudéssemos formular respostas mais ou menos diretas ou indiretas a essas questões, fundamentamos teórica e metodologicamente nosso estudo na Análise de discurso. Com base nessa fundamentação, analisamos alguns enunciados extraídos de um corpus constituído por textos dos jornais Folha de São Paulo e O Estado de São Paulo e das revistas Veja e Época, publicados desde 1989 até nossos dias.

\section{Poder dizer, dever calar: democracias de direito e preconceitos de fato}

Em cenários nos quais formalmente se goza dos benefícios da liberdade de expressão, o exercício desse direito não se estende indistintamente a todos os falantes de uma comunidade linguística, uma vez que os preconceitos e discriminações contra os meios populares de expressão estão presentes nos contextos frequentemente concebidos como os mais favoráveis ao diálogo e à comunicação racional no espaço público: a democracia na Grécia clássica, a república em Roma, as Luzes na Europa etc. Em outros termos, nas experiências históricas de recrudescimento da liberdade de expressão, ainda que elas sejam mais ou menos idealizadas, o desprezo pela fala e pela escuta do povo e as difamações que elas sofrem são, guardadas as devidas proporções e diferenças, uma continuidade de censura por outros meios. Tal como o demonstramos em outros lugares (cf. PIOVEZANI, 2016, p.82-92), mesmo o campo da retórica, qualificada frequentemente como campo e exercício fundamentalmente democráticos e republicanos, está eivado de condenações à voz e à escuta do povo. Poderíamos dizer que, novamente mutatis mutandis, foi isso que vimos ocorrer no Brasil em recentes capítulos de sua história, mais precisamente no período imediatamente seguinte ao final de ditadura civil-militar, que se estendeu de 1964 a 1985. Conforme sabemos, cinco anos depois do início do governo civil, cujo presidente da República foi eleito por voto indireto do congresso nacional, aconteceriam as eleições diretas em 1989.

Naquela ocasião, Luiz Inácio Lula da Silva, que havia sido operário, líder sindical e deputado na assembleia nacional, apresentou-se como candidato, assim como o faria novamente em 1994 e em 1998, eleições nas quais foi derrotado, e em 2002 e 2006, das quais saiu vitorioso. O período que se inicia em 1985 é frequentemente chamado de "abertura democrática", o que acarretava a ideia de que desde então não havia mais os limites e censuras 
EID\&A - Revista Eletrônica de Estudos Integrados em Discurso e Argumentação, Ilhéus, n. 16 esp. "Discurso e argumentação na política latino-americana, set.2018.

explícitas à liberdade de expressão. Isso não significava, porém, que o espaço público estivesse pronto a acolher sem restrições e discriminações a própria voz do povo ou a fala daquele que então se apresentava como seu porta-voz ${ }^{1}$. Foi, antes, o inverso que se produziu: a visibilidade e a importância de alcance nacional adquiridas por alguém oriundo de uma classe socioeconômica miserável e que não dispunha das credenciais e do nível de educação formal requeridos para o postulante a um tal cargo, acrescentadas à possibilidade crescente de seu sucesso eleitoral, radicalizaram os discursos e as atitudes discriminatórias.

Além disso, a naturalização dessas discriminações ganhou uma potência e uma abrangência inéditas, na medida em que eram produzidas ou transmitidas por veículos da grande mídia brasileira. Com efeito, não é por geração espontânea que surgem os preconceitos e intolerâncias nem tampouco por propriedades intrínsecas dos sujeitos que são suas vítimas. Aprendemos com Pêcheux (1990 e 1997, entre outros) que as constantes lutas de classes e as demais relações de força que se processam no interior de uma sociedade materializam-se em ideologias, que, por sua vez, materializam-se em práticas, entre as quais as práticas discursivas desempenham um papel privilegiado nessa materialização ideológica. A história das lutas sociais não apenas estará refletida nos textos que produzimos, mas também, e sobretudo, os constituirá no próprio âmago de suas formulações, nas quais se materializam os discursos. Ao fenômeno, a tradição dos estudos do discurso dá o nome de historicidade, em consonância com o postulado de Michel Foucault (1997), segundo o qual os enunciados não devem ser tomados como "documentos", que espelhariam as realidades de que falam, mas como "monumentos", em cujas composições se inscrevem as relações de saber e de poder entre os sujeitos de uma sociedade.

Pêcheux e Foucault, cada um a seu modo, ensinam-nos que diante dos dizeres frequentemente muito semelhantes entre si é preciso identificar a posição da qual cada um deles provém. A partir das ponderações de Foucault sobre o discurso, é possível afirmar que há um descompasso entre tudo o que, com base na língua e na lógica, se poderia dizer e aquilo que é efetivamente dito numa sociedade. Em conjunção com essa diferença forjada e gerida pela história entre a generosa potência e os atos rarefeitos ocorre uma outra, que consiste na separação, em tudo o que foi dito, entre os textos e enunciados

\footnotetext{
${ }^{1}$ Sobre a noção de porta-voz, ver Pêcheux (1990), Zoppi-Fontana (1997) e Ramos (2013).
} 
EID\&A - Revista Eletrônica de Estudos Integrados em Discurso e Argumentação, Ilhéus, n. 16 esp. "Discurso e argumentação na política latino-americana, set.2018.

que serão mais ou menos conservados e aqueles que serão mais rapidamente esquecidos. A reflexão sobre o controle do dizer e de sua maior ou menor conservação está sintetizada na definição que Foucault consagra à noção de arquivo, que consiste num conjunto de regras que, em uma época dada e por uma sociedade determinada, definem aquilo de que é possível se falar, os dizeres a serem conservados ou apagados, os que permanecerão válidos, que se tornarão discutíveis e os que serão invalidados, em que campos e por quais sujeitos eles poderão ser ditos.

Em uma de suas conceituações da noção de arquivo, Foucault o concebe como "a lei do que pode ser dito, o sistema que rege o aparecimento dos enunciados como acontecimentos singulares", acrescentando que ele é também responsável pelo fato de que "todas as coisas ditas não se acumulem indefinidamente em uma massa amorfa, não se inscrevam, tampouco, em uma linearidade sem ruptura e não desapareçam ao simples acaso de acidentes externos, mas que se agrupem em figuras distintas, se componham umas com as outras segundo relações múltiplas, se mantenham ou se esfumem segundo regularidades específicas; ele é o que faz com que não recuem no mesmo ritmo que o tempo, mas que as que brilham muito forte como estrelas próximas venham até nós, na verdade de muito longe, quando outras contemporâneas já estão extremamente pálidas." Nesse sentido, o arquivo "é o que diferencia os discursos em sua existência múltipla e os especifica em sua duração própria. (1997, p. 149).

A série de enunciados, que reproduzimos logo abaixo, demonstra que as performances oratórias de Lula, um orador proveniente das classes populares e da atuação sindical e um representante em alguma medida contíguo das classes trabalhadoras brasileiras, sempre sofreram julgamentos depreciativos e deslegitimantes. Os discursos e as ações que descreditam a fala pública marcada pelos traços populares, tanto quanto a escuta popular dessa e de outras falas públicas, atravessam a longa duração histórica e as fronteiras do espaço, dos campos institucionais e dos campos de saber e são ainda onipresentes no Brasil contemporâneo. Tais discursos veem em Lula, antes, durante e depois de seus mandatos como presidentes da República, um alvo privilegiado. 
EID\&A - Revista Eletrônica de Estudos Integrados em Discurso e Argumentação, Ilhéus, n. 16 esp. "Discurso e argumentação na política latino-americana, set.2018.

\section{O desempenho oratório de Lula na imprensa brasileira}

\subsection{Dizeres sobre a fala pública do candidato}

A propaganda de Lula, à noite, procurou conter um pouco a agressividade. $O$ programa voltou a atacar Collor, mas deu também espaço para um discurso em que Lula tentou se aproximar da classe média. O objetivo é escapar da retórica de porta de fábrica e acalmar os eleitores assustados com o radicalismo do primeiro turno. (Folha de São Paulo, caderno Diretas, "Lula faz discurso para tranquilizar classe média”, 30 de novembro de 1989, p. 6)

Como aconteceu em outros debates, Lula escorregou no vernáculo. O candidato deixou algumas perguntas sem resposta. Uma delas foi quando um dos entrevistadores quis saber se ele coagiria a oposição caso houvesse uma reação ao seu governo. Em outras perguntas, lançou mão de frases de efeito para fustigar seu adversário. (Folha, caderno Diretas, "Lula usa discurso moderado como tática eleitoral”, Emanuel Neri, 15 de dezembro de 1989, p. B2)

É verdade que Lula continua menor que Brizola e tem apenas um terço do eleitorado de Fernando Collor de Melo. A questão concreta da atual fase de campanha, entretanto, é que o candidato do PT com sua barba de camponês, sua barriga de Pancho Villa e seus erros de concordância de quem não completou o curso ginasial tornou-se um concorrente com chances de, ao menos em tese, instalar-se futuramente na residência oficial do chefe da nação, com pompa, com fraque e com o direito constitucional de fazer e acontecer, por mais que sua visão esquerdista possa assustar todos aqueles que terão de tratálo como presidente da República. Um espanto. [...] Lula faz uma campanha com o apetite de quem pretende chegar lá [...] e diz, com sua voz grossa e rouca, que pretende fazer um governo que beneficie os pobres e prejudique os ricos. (Veja, “Lula entra no jogo", 18 de outubro de 1989, ano 22, n 41, edição 1101, p. 45)

Como líder dos metalúrgicos no $\mathrm{ABC}$, Lula passou 10 anos batendo na porta dos mais ilustres gabinetes da indústria paulista para pedir aumento salarial aos empregados. Agora, se levar a melhor sobre seu adversário no segundo turno das eleições, o primeiro colocado Fernando Collor, pode acontecer de os maiores empresários do país serem obrigados a marcar audiência para serem recebidos no $3^{\circ}$ andar do Planalto por um operário barbudo, que fala português errado e não tem o dedo mínimo na mão esquerda. Esse candidato, Lula, faz perguntas que o eleitorado de Collor entende e, embora use sua gramática tumultuada e não tenha o invólucro elegante do ex-governador de Alagoas, fala numa língua entendida pelo mesmo público. (Veja, “A arrancada de Lula”, 22 de novembro de 1989 , ano $22, n^{\circ} 46$, ed. 1106 , p. 54 e 66 )

Muita gente que assistiu ao debate se divertiu com os tropeços de Lula na gramática. O candidato trocou tempos verbais, mudou o advérbio menos para menas e chegou a criar uma nova expressão - a promessa de gatos e sapatos. Com um vocabulário pequeno, ele se valeu, no debate, de seu raciocínio rápido e do uso de frases curtas e coloquiais, fáceis de entender. [...] Lula fez um discurso emocionado para a platéia de mais de 10.000 pessoas que se aglomeravam em frente à prefeitura da cidade, usou sua arma mais conhecida - a linguagem popular e agressiva. (Veja, “Debates. Cenas secretas”, 13 de dezembro de 1989, ano 22, n 49, edição 1109, p. 54 e 59) 
EID\&A - Revista Eletrônica de Estudos Integrados em Discurso e Argumentação, Ilhéus, n. 16 esp. "Discurso e argumentação na política latino-americana, set.2018.

A fala de Lula é manifesta e reiteradamente avaliada como agressiva e, quando não o é tanto assim, consistiria numa simulação de não o ser ou se limitaria a uma mera tentativa de "conter um pouco a agressividade". De modo análogo, as propostas endereçadas à classe média são apresentadas como tentativas de sua propaganda eleitoral para se aproximar desse setor da sociedade, ou seja, como uma estratégia de manipulação. Por outro lado, sua "retórica de porta de fábrica" - expressão na qual distinguimos facilmente o julgamento elitista do enunciador que a utiliza -, "o radicalismo" e a condição de "assustados" dos eleitores seriam práticas, fenômenos e estados reais e evidentes. Os sintagmas nominais determinados por artigos definidos ("a agressividade"; "O objetivo"; “da retórica de porta de fábrica”; “o radicalismo"; e "os eleitores assustados"; neste último, há ainda a evidência do estado anímico dos eleitores, expressa no adjetivo, sob a forma reduzida de uma oração adjetiva restritiva) são pré-construídos que produzem o efeito de evidência de cada um desses elementos. Enfim, há ali ainda outra oposição fundamental que vai acompanhar os comentários midiáticos sobre Lula durante toda sua vida pública: ele seria um ser duplo, um indivíduo bifronte, porque é violento e radical - seja ele movido por astúcia seja motivado por franqueza -, mas se mostra igualmente calmo e tranquilo, seja no intuito de simular e de dissimular o que realmente é, seja para tentar agradar todo mundo. A partir da posição do enunciador da mídia hegemônica, Lula é, portanto, um homem de duas caras, a da violência e a do diálogo, tal como um Janus brasileiro e decaído da pior espécie. Esse enunciador produz assim e ao mesmo tempo o efeito de que nos revela a verdade do que ele próprio denuncia e o de que ele aponta as mentiras, os segredos e as estratégias de Lula.

Sua fala seria agressiva, assim como sua língua, deformada. Quando o foco das avaliações midiáticas recai sobre o que consideram ser os erros e as inconsistências dessa última, esses tais equívocos são descritos como algo que não cessa de se repetir: "Como aconteceu em outros debates, Lula escorregou no vernáculo". A suposta reincidência das incorreções gramaticais é mencionada com uma ironia, plena de desdém, mediante o emprego de "escorregou", expressão coloquial, sugestiva e sarcástica. Além disso, seu desempenho é ainda observado a partir do que teria sido outra estratégia retórica: deixar sem resposta algumas questões, o que indicaria seu déficit de conhecimento - reiteradamente se dizia que Lula não estava "preparado" 
EID\&A - Revista Eletrônica de Estudos Integrados em Discurso e Argumentação, Ilhéus, n. 16 esp. "Discurso e argumentação na política latino-americana, set.2018.

para o cargo de presidente; isto é, se tratava de uma maneira mais ou menos indireta de se referir ao fato de que ele não possuía educação formal suficiente - e responder a outras, valendo-se de "frases de efeito". Se o emprego dessas frases já depõe contra o orador, utilizá-las "para fustigar seu adversário" é ainda mais grave. Estaríamos aí diante de uma tática oportunista para um fim não menos perverso. Não é tampouco devido ao acaso o fato de que o enunciador afirme que uma das questões deixadas sem resposta tenha sido justamente aquela que indagava "se ele coagiria a oposição caso houvesse uma reação ao seu governo". Nesse discurso, o silêncio de Lula equivale e se encadeia com sua astúcia, seu radicalismo e sua agressividade e produz o efeito de confirmação de uma conduta já conhecida, mas sem coragem para ser confessada.

Os enunciados sobre o desempenho oratório do então candidato produzidos a partir da posição discursiva da tradicional mídia brasileira tendem a ser ainda mais chocantes e ofensivos, quando o perfil do candidato é traçado pela revista Veja, por meio da exposição manifestamente preconceituosa e discriminatória de sua língua, de seu corpo e de sua voz: "o candidato do PT com sua barba de camponês, sua barriga de Pancho Villa e seus erros de concordância de quem não completou o curso ginasial"; "sua voz grossa e rouca"; "um operário barbudo, que fala português errado e não tem o dedo mínimo na mão esquerda"; "embora use sua gramática tumultuada e não tenha o invólucro elegante". A crueza e a crueldade das expressões não deixam a menor dúvida da alta conta em que a revista tem todos aqueles que trazem em si as marcas reais ou imaginárias de pertença ou proveniência das classes populares, em geral, e Lula, em particular. O que poderia ser concebido como seus trunfos ou como suas capacidades linguísticas e oratórias- "faz perguntas que o eleitorado de Collor entende"; "fala numa língua entendida pelo mesmo público"; "uso de frases curtas e coloquiais, fáceis de entender"; e "um discurso emocionado" -, assim como sua presença de espírito ("seu raciocínio rápido") e seu senso de ocasião, o que, aliás, sempre foi uma preocupação maior da retórica, à qual os gregos antigos chamavam de kairos, tornam-se fraquezas ou trapaças ou são ainda drasticamente depreciadas relativamente ao enorme conjunto do que os precede e os sucede. Além das expressões ultrajantes mencionadas logo acima, há ainda apenas nesses fragmentos de Veja as seguintes: "os tropeços de Lula na gramática"; "sua arma mais conhecida - a linguagem popular e agressiva"; e "um vocabulário pequeno". Ou seja: "discurso emocionado" é 
EID\&A - Revista Eletrônica de Estudos Integrados em Discurso e Argumentação, Ilhéus, n. 16 esp. "Discurso e argumentação na política latino-americana, set.2018.

parafraseado por "linguagem popular e agressiva", tal como ocorre desproporcionalmente com cada elemento que pudesse conter algum valor eufórico em sua performance de linguagem. Ademais, a sombra da acusação do sujeito de duas caras continua a rondar e a marcar o Lula candidato.

As alegadas evidências da agressividade das falas de Lula, de sua língua deformada e da condição bifronte do candidato, mas também sua desidentificação com o habitus de voz, comportamento e vestuário burgueses são apresentadas em formulações veementes, quando não ofensivas e hostis, a despeito do eventual efeito de humor no enunciado: "Muita gente que assistiu ao debate se divertiu com os tropeços de Lula na gramática. $O$ candidato trocou tempos verbais, mudou o advérbio menos para menas e chegou a criar uma nova expressão - a promessa de gatos e sapatos." A pressuposta diversão de "muita gente" e os eventuais risos derivados dos "tropeços de Lula na gramática" e da criação de uma expressão rapidamente cedem lugar ao tom grave e amargo que se produz com os enunciados e expressões que os emolduram contextualmente - "O candidato trocou tempos verbais, mudou o advérbio menos para menos"; "um vocabulário pequeno"; "sua arma mais conhecida - a linguagem popular e agressiva" - e com os já-ditos bastante consolidados do interdiscurso sobre as deficiências e deselegâncias dos usos e hábitos linguísticos e comportamentais do povo pobre. Mas nem só de agressividade manifesta vivem os preconceitos e discriminações. Isso porque eles podem adquirir uma outra aparência e contar, desta feita, com a força de certa sutileza, ou seja, com a potência do que é dito de maneira discreta e anódina ou do que é formulado com a leveza do humor, provavelmente mais bem-sucedido em diferentes correntes ideológicas. Assim, o enunciador pode criar a distância e a distinção social entre si mesmo e seu enunciatário, isto é, seu grupo de distintos, por um lado, e Lula e os sujeitos das classes populares, com suas expressões e costumes equivocados, ridículos ou grosseiros, por outro, sem a gravidade dos ataques explícitos. É exatamente o que se pode observar, entre tantos outros, nos fragmentos que reproduzimos a seguir:

O PT faz uma homenagem à Revolução Francesa e lança o seu sonoro slogan: o "Lula lá". Aliás, o Lulalá tá cada dia mais chique: usa gravata, grita ulalá e sua meta é uma metalúrgica. Só falta aprender piano. (Folha, caderno Diretas, José Simão, 17 de setembro de 1989, p. B. 4)

E deu na Internet que o Lulalelê e o Vicentinho estão lançando "O Manual de Dicção das Lideranças Sindicais de São Paulo". Liççção sssessenta e ssseiss: nesssssas eleiççções ssiga sssseu coraçççção, quem ssssabe é quem ssssente. A 
EID\&A - Revista Eletrônica de Estudos Integrados em Discurso e Argumentação, Ilhéus, n. 16 esp. "Discurso e argumentação na política latino-americana, set.2018.

sssituaççção essstá péssssima! Asssocccie-ssse ao nosssso ssssindicato!" (Folha, caderno Eleições, José Simão, 01 de outubro de 1998, p. 1)

\subsection{Dizeres sobre a fala pública do presidente}

O falar errado de Lula não constitui um dado isolado e sem consequências. Sua "palavra tosca" arrasta consigo o "pensamento banal", que, por sua vez, responde pelo "ato irrelevante". As aberrações linguísticas condicionam a banalidade do pensamento e a irrelevância dos atos de um governo sem forma nem figura de governo. Se tudo se limitasse aos erros gramaticais de Lula, seria fácil absolvê-lo.

Mas o que denunciam aqueles erros não se resume à quebra das regras acadêmicas da linguagem, e sim algo muito mais grave - o simplismo das ideias, inadequado à complexidade dos problemas de governo, e a ineficácia da conduta, limitada a medidas irrelevantes, isto é, paliativas.

Dirão os incautos que Lula, homem do povo, tem o direito, e até a obrigação, de falar errado. [...]

Aqui é que mora a dúvida. Lula fala, mesmo, a língua do povo? Basta falar errado para falar a língua do povo? Sabemos que a língua popular, na sua informalidade, tem sabores insubstituíveis e é vivamente expressiva, quer na versão da fala plebeia da população, quer na versão caipira, ou na versão sertaneja. [...] Fica evidente que Lula, por mais populista que quisesse ser, nunca poderia adotar, na íntegra, nem a língua caipira, nem a do sertanejo, nem a de Adoniran Barbosa, sem cair no ridículo atroz. Lula não é “doutor”, mas também não é caipira, nem sertanejo, e há muito tempo deixou de ser o pau-de-arara, emigrado do Nordeste. Seu perfil mais autêntico é o de membro da elite metalúrgica do $A B C$, camada diferenciada de trabalhadores, da qual saem os grandes líderes sindicais, que se recusam a falar errado (Paulinho, Marinho, Feijó e outros).

Então, o que faz Lula? A fim de parecer homem do povo, ele se limita a maltratar a língua, engolindo os esses, violentando a sintaxe, forçando erros de concordância, como se isso bastasse para "falar gostoso o português do Brasil". Em suma, Lula forja um arremedo da língua popular, distante tanto dos padrões da linguagem formal, como dos usos legítimos da fala popular (caipira, sertaneja ou periférica). O discurso de Lula degenera num Frankenstein assustador: "A gente tem que ser gentis", soltou outro dia. [...]

O povo também estropia a língua, mas com inocência. Na fala estropiada de Lula há de tudo, menos inocência. (Estado de São Paulo, caderno Espaço Aberto, Gilberto de Mello Kujawski, "O linguajar de Lula”, 17 de fevereiro de 2005, p. A2)

O que inicialmente se ressalta nesse texto que passamos a considerar e que nele funciona como fundamento de sua própria razão de ser consiste na relação que seu enunciador pretende estabelecer entre a crítica da aparência, isto é, o que ele diz sobre a fala de Lula, e o que seria a crítica de algo bem mais sério e grave: os pensamentos e os atos do presidente ${ }^{2}$. Sabemos que

\footnotetext{
2 Marli Quadros Leite (2008) dedicou uma análise ao texto “Em nome da lei do pior esforço", de Dora Kramer, igualmente publicado no Estadão (edição do dia 26 de janeiro de 2005), no qual a jornalista sustenta haver uma atitude populista no que seria uma opção deliberada de Lula em falar "incorretamente" e denuncia o efeito perverso decorrente dessa opção por um "companheirês que desqualifica o idioma", uma vez que sugeriria aos menos instruídos que esse modo de
} 
EID\&A - Revista Eletrônica de Estudos Integrados em Discurso e Argumentação, Ilhéus, n. 16 esp. "Discurso e argumentação na política latino-americana, set.2018.

esse tipo de articulação entre o exterior do corpo e de seus signos, que podemos ver, ouvir, tocar e experimentar, de um lado, e o interior dos homens, o que se passaria em seus corações, em suas cabeças e em suas almas, esteve e está constantemente presente em diferentes contextos históricos. É muito provável que ela tenha se configurado como uma constante antropológica no modo de se proceder às interpretações que fazem os seres humanos de seus semelhantes. Pois é justamente a partir de algo tão absolutamente consolidado nas maneiras de sentir e de pensar que esse texto descredita a fala de Lula e, por extensão, sua capacidade de julgamento, suas decisões e medidas, ao produzir o efeito de que pretende discorrer essencialmente sobre seu desempenho oratório. Assim, a crítica pode se tornar ao mesmo tempo mais crível e pertinente, na medida em que não será difícil que os leitores do Estadão sejam conduzidos por um processo discursivo que se assenta em esquemas do tipo: exterior/interior, forma/conteúdo, linguagem/pensamento, atos/palavras etc. Peso e valor suplementares adicionam-se, portanto, à crítica, uma vez que ela trata da fala de Lula, certamente, mas para visar um alvo mais relevante e prejudicial, os programas e as ações do governo do PT.

Frequentemente condenada em Lula, a agressividade, desta vez presente nas próprias formulações do texto de Kujawski, surge sem disfarces ou nuances: a "palavra tosca" é índice de "pensamento banal" e de "ato irrelevante". O léxico dessa adjetivação não deixa dúvida alguma. Aqui a força do preconceito cumpre uma função decisiva, porque os traços populares da fala de Lula são apresentados, em conformidade com a concepção hegemônica, como erros. Essa suposta evidência, por sua vez, pode produzir o efeito de que os pensamentos e os atos do presidente são do mesmo modo e evidentemente equívocos, com o agravante de que a banalidade e a irrelevância não seriam inócuas, tendo em vista o mau exemplo linguístico e comportamental dado por Lula e as consequências tão ou mais danosas de suas decisões e ações governamentais.

O enunciador sugere ainda que as características populares da fala de Lula seriam uma artimanha e uma marca de seu populismo. Corresponderiam a uma simulação da condição popular, no intuito de um benefício próprio. Não se trata aqui do questionamento de um porta-voz, para denunciar a 
EID\&A - Revista Eletrônica de Estudos Integrados em Discurso e Argumentação, Ilhéus, n. 16 esp. "Discurso e argumentação na política latino-americana, set.2018.

confiscação da própria voz do povo, nas circunstâncias em que ela estaria sendo representada e, por isso, em boa medida, silenciada, por alguém que não pertence efetivamente às camadas populares; nem se trata tampouco da defesa do direito dos sujeitos das classes exploradas e desfavorecidas de falar por si mesmos e com suas próprias vozes. Além disso, tanto no texto de Kujawski quanto no de Kramer, podemos facilmente identificar em conjunto com a ênfase e a violência de suas formulações uma considerável carga de ironia em seus ataques que vão da performance oratória de Lula ao seu caráter: "populismo desabrido"; "companheirês que desqualifica o idioma"; "agredindo o português, sem deixar quase nenhuma frase incólume"; "as aberrações linguísticas"; "a banalidade do pensamento"; "a irrelevância dos atos de um governo sem forma nem figura de governo"; "ridículo atroz"; "Lula forja um arremedo da língua popular"; "O discurso de Lula degenera num Frankenstein assustador"; e "Na fala estropiada de Lula há de tudo, menos inocência".

Finalmente, é preciso ressaltar nesse discurso conservador e intolerante uma condescendência igualmente ferina. Postura, esta sim, populista, que consiste em reconhecer a "beleza do morto" (cf. DE CERTEAU et al., 1989), ou seja, uma atitude que corresponde a conceber as ações e manifestações populares como tanto mais belas quanto mais inofensivas. Numa concepção elitista e folclórica, a voz do povo pode ter graça e encanto, desde que seja embalsamada, exótica e inócua, porque devidamente inerte ou exclusivamente animada nos limites do espetáculo que diverte. Na esfera pública, no cenário da política nacional, busca-se impedir que o povo fale, mesmo que sua manifestação não seja mais do que um resto, porque feita por um seu porta-voz que já não mais fazia parte dos plebeus, proletários e dominados, mas que guardava ainda em sua fala as marcas de classe que continuavam a ser objeto privilegiado de perseguição. $O$ enunciador não reconhece nem disfarça o engodo que o envolve e que ele reproduz: "a língua popular [...] tem sabores insubstituíveis e é vivamente expressiva"..., mas só "na sua informalidade".

\subsection{Dizeres sobre a fala pública do ex-presidente}

O presidente que cometeu mais gafes na história do Brasil conseguia quase sempre roubar a cena ao abrir a boca. [...] Sua voz rouca, com erros de português, metáforas de futebol e piadas do povão, era o elo com a massa, na versão sindicalista exaltado ou do lulinha paz e amor. O Brasil teve outros 
EID\&A - Revista Eletrônica de Estudos Integrados em Discurso e Argumentação, Ilhéus, n. 16 esp. "Discurso e argumentação na política latino-americana, set.2018.

oradores inflamados [...] que se expressavam com vigor também na escrita. Lula não. Exerce uma liderança oral. A maioria da população brasileira não domina a palavra escrita. [...] Num país assim, a voz é hipervalorizada como capital simbólico. Lula sempre falou demais. (Época, Ruth de Aquino, 30 de março de 2012)

O relativo reconhecimento da capacidade comunicativa de Lula e mesmo de sua eloquência - "conseguia quase sempre roubar a cena ao abrir a boca" é precedido pelo que se apresenta como um dado real, grave e evidente: "O presidente que cometeu mais gafes na história do Brasil”. Com efeito, trata-se aqui de um julgamento que não tem coragem nem vontade de se assumir como tal e que se dissimula sob a forma de uma constatação, cujo acolhimento seria feito sem objeções. A popularidade do ex-presidente, devida em larga medida a seu talento oratório, é também ela reconhecida para ser mais bem e imediatamente questionada e deslegitimada. Porque seu "elo com a massa", aqui compreendidos todos os preconceitos antiquíssimos e sempre presentes que recaem sobre esta última, somente se produz por meio da voz e da fala, ambas supostamente plenas de falhas, erros e mau gosto: "Sua voz rouca, com erros de português, metáforas de futebol e piadas do povão". Como de costume, a duplicidade de Lula é onipresente; desta feita, inclusive, apontada com ironia aberta e hostil: "na versão sindicalista exaltado ou do lulinha paz e amor"; assim como, apesar de sua relativa discrição, seu estilo veemente, como seria típico dos "oradores inflamados" da eloquentia popularis. Em suma, a competência retórica de Lula é subsumida numa série de alegadas impropriedades, que a questionam, desqualificam e a transformam no avesso de qualquer aptidão legítima.

Cabe, além disso, às duas modalidades linguísticas cumprir seus papéis na oposição fundamental, que herdamos de concepções antigas e modernas, registradas nas páginas da filosofia grega clássica e na das Luzes: de um lado, situam-se a escrita, as letras e os letrados, a leitura, o mundo das ideias e a autonomia do espírito e da razão; de outro, estariam a oralidade, a voz e os iletrados, a fala e a escuta, o mundo sensível, o aprisionamento do corpo e a manipulação pelas emoções. As relações entre a liderança que seria exclusivamente oral e a massa que somente pode contar com sua deficiente escuta não poderiam ser afirmadas de modo mais explícito, preconceituoso e intolerante. Desde os antigos, vimos que já se impunha a ideia de que a voz e fala só poderiam ser bem aceitas, caso viessem em estilo "correto, límpido, elegante e bem adaptado" e em emissão vocal “fácil, nítida, agradável, bem 
EID\&A - Revista Eletrônica de Estudos Integrados em Discurso e Argumentação, Ilhéus, n. 16 esp. "Discurso e argumentação na política latino-americana, set.2018.

romana, isto é, sem sotaque campesino nem estrangeiro". Em Aristóteles e em Cícero, conforme notamos aqui mesmo acima, mas também entre pregadores medievais e entre os cronistas modernos dos gritos de Paris, passando ainda pela psicologia social de Gustave Le Bon e pela literatura realista de Émile Zola ${ }^{3}$, podemos observar essa estratégia constante de acordo com a qual se deprecia ao mesmo tempo os oradores populares e a escuta das pessoas do povo, mediante esse dispositivo de transferências recíprocas das deformidades e dos estigmas de uns aos outros, que por seu turno produz a deslegitimação de ambos. Para fazê-lo, o mecanismo vale-se invariavelmente da remissão das aparências às essências, das expressões aos conteúdos etc. Assim, as "gafes" podem ser admitidas como tais, em função da evidência construída em torno da "voz rouca" e da fala plena de "erros de português, metáforas de futebol e piadas do povão". Cadinho das gafes, dos erros, da ignorância e do mau gosto, a massa e o povão não poderiam ser mais bem atraídos do que por aquilo que impregna o que seria sua própria essência. Tal como o indicamos, na esfera pública, no cenário da política nacional, qualquer palavra do povo ou de um seu representante que porta em seu corpo e em sua voz as marcas populares torna-se excesso: "Lula sempre falou demais."

\section{Considerações finais}

À fala pública de Lula foram constantemente atribuídas a inaptidão linguística, e não raras vezes até mesmo uma ausência absoluta de qualquer habilidade com a língua, como se sua fala não fosse mais do que uma soma de erros ("agredindo o português, sem deixar quase nenhuma frase incólume"; "as aberrações linguísticas" etc.), e se limitasse à rudeza de seus modos de expressão. As descrições, os julgamentos e as classificações de seu desempenho oratório depreciam, portanto, sua língua, mas nem por isso poupam seu corpo e sua voz, invariavelmente objetos de qualificações que vão do desdém aos ataques manifestos e aviltantes. Além disso, reiteradamente se afirma que sua linguagem é agressiva e, quando Lula passa muito ao largo de alguma ênfase ou de qualquer indício assertivo, optando por tons amenos e pela abertura ao diálogo, a acusação de sua condição

\footnotetext{
${ }^{3}$ Conferir, respectivamente: GIRONÈS, M. B.; BEAULIEU, M. A. P. (Dir.) Prédication et performance: du XIlè au XVlè siècle. Paris, Classiques Garnier, 2013; MILLOT, Vincent. "Les Cris de Paris, figures d'un peuple apprivoisé". Revue de la BNF, Dossier "De quoi le peuple est-il le nom?", Paris, BNF Éditions, n. 52, 2016, p. 12-25; e COURTINE, J-J. "A voz do povo: A fala pública, a multidão e as emoções na aurora da era das massas". In: COURTINE; PIOVEZANI, op. cit.
} 
EID\&A - Revista Eletrônica de Estudos Integrados em Discurso e Argumentação, Ilhéus, n. 16 esp. "Discurso e argumentação na política latino-americana, set.2018.

bifronte está sempre presente. A partir de uma posição ideológica conservadora, os enunciadores da mídia tradicional rotulam de "radical" o porta-voz que denuncia a miséria e reivindica melhoria das condições de vida das classes trabalhadoras e populares e de "duas caras" aquele que busca negociar e arrefecer as resistências às suas propostas. Provavelmente tão cego ao seu preconceito quanto convicto da realidade do que ouve e vê, o sujeito desse discurso crê descrever um fenômeno, quando emite suas opiniões e formula suas avaliações: "Lula usa discurso moderado como tática eleitoral"

Salvo por esse que é apresentado como um dos principais estratagemas retóricos de Lula, a saber, suas tentativas de agradar a todos - os operários e os empresários, os ricos, os pobres, mas também a classe média...-, as demais propriedades e características imputadas a suas performances oratórias tendem a conduzir para a mesma direção: o rebaixamento de uma fala humana à condição de um ruído da natureza, a diminuição do logos à phoné, numa palavra, a redução da vox, da linguagem dirigida e devotada ao outro semelhante da espécie humana, ao rumor, a uma confusão sonora e bestial (cf. SALAZAR; PIOVEZANI, 2016). Assim, a força da fala de Lula é minada e perde ao menos uma boa parte de seu poder, tal como já tende a ocorrer mesmo com as discretas propostas progressistas de alguma transformação social formuladas no que se poderia considerar como o registro de linguagem formal, o estilo elegante e na mais perfeita "correção" gramatical. Se tais proposições com esse belo invólucro já são alvejadas pela retórica reacionária (cf. ANGENOT, 2005, p. 101-104), tanto mais o serão aquelas que estiverem marcadas pelos traços indexados ao povo pobre e que, com essa aparência, pretendem algum real poder transformador e algum alcance fora do folclore e do espetáculo. Vários séculos e um oceano não são suficientes para arrefecer as ofensivas elitistas. Na discriminação midiática do desempenho oratório de Lula, não estamos distantes dos recursos e estratégias de depreciação da eloquentia popularis, de outros e longínquos tempos e lugares.

Ao menos desde Cícero, se repete essa deslegitimação da fala com marcas da fala do povo e mais ou menos endereçada aos ouvintes populares, ao Ihe acusar a falta de urbanitas. Entretanto, não se pode sustentar que entre a Roma antiga e o Brasil contemporâneo, passando pelas Revoluções francesa, americana e russa e por conquistas políticas e sociais arrancadas com inúmeras e dolorosas lutas também por aqui, nada tenha se modificado. 
EID\&A - Revista Eletrônica de Estudos Integrados em Discurso e Argumentação, Ilhéus, n. 16 esp. "Discurso e argumentação na política latino-americana, set.2018.

Alguns instantâneos de uma história da fala pública popular e da escuta popular da fala pública poderiam ser suficientes para demonstrar a longa duração dos estigmas da deformidade e da violência atribuídos à língua, ao corpo e à voz dessa fala, que, é preciso dizê-lo, é antes dirigida ao povo do que propriamente do povo, e daqueles da impulsividade, da volubilidade e da ignorância da escuta das classes pobres e marginalizadas. A atribuição desses preconceitos conhece ainda uma grande força e um alcance de longo fôlego, que são, conforme reiteramos, suficientemente potentes para ultrapassar limites do tempo e do espaço e ainda outras fronteiras. Contudo, isso não significa que as discriminações da voz do povo e/ou de seus porta-vozes, que apresentem também eles traços populares em suas manifestações e comportamentos, e ainda da escuta das massas plebeias são exatamente idênticas em suas formas e conteúdos.

Entre as modificações produzidas no interior dos discursos sobre as práticas de fala e de escuta populares, é preciso ressaltar ao mesmo tempo a emergência de um lugar sem precedentes à voz e à recepção do povo a partir da segunda metade do século XIX e de certa tendência a dissimular os preconceitos que incidem sobre elas ou a atenuá-los, por meio de formulações mais sutis. Essa tendência geral não impede a reiteração das discriminações, desde as mais discretas até as mais violentas, mas produz transformações importantes sobre os efeitos desencadeados por estas últimas. Se assim não fosse, a possibilidade de uma reação como esta - "A linguagem de Luiz Inácio Lula da Silva é a do povo, a que o povo entende." (Folha, Painel do leitor, Aldo Lins e Silva, 15 de dezembro de 1989, p. A3) -, ainda que ela continue a ser minoritária, seria praticamente nula. Em contrapartida, as condenações da linguagem popular, em geral, e a de suas manifestações públicas, em particular, tal como ocorre com Lula (cf. PIOVEZANI, 2015, p.324-330), continuam a ser hegemônicas.

Um dos efeitos mais nefastos dessas condenações do desempenho oratório de Lula é justamente a discriminação e a deslegitimação da voz e da escuta populares. Assim, a política e a psicologia tornam-se talvez mais do que nunca inextrincavelmente ligadas: a garantia fundamentada na certeza de um julgamento positivo de sua performance linguística produz uma fala e um sujeito seguros de si mesmos, ao passo que a timidez e a insegurança, que antecipam sanções negativas, embargos e ataques, produzem não raramente o silêncio e a ausência ou, ao menos, uma grande insuficiência das iniciativas 
EID\&A - Revista Eletrônica de Estudos Integrados em Discurso e Argumentação, Ilhéus, n. 16 esp. "Discurso e argumentação na política latino-americana, set.2018.

emancipadoras e cidadãs. Ao eleger eleitos e rebaixar rebaixados, mediante discriminações e deslegitimações da expressão popular, o que se pretende condenar é a voz pela qual o povo expressa suas dores e suas queixas, o que se pretende calar são suas justas reivindicações e suas necessárias revoltas, impondo-lhes que a "dupla e irremediável exclusão de viver como operários e falar como burgueses".

\section{Referências}

ANGENOT, Marc. $\mathbf{O}$ discurso social e as retóricas da incompreensão. Organização e apresentação de Carlos Piovezani. São Carlos: EdUFSCar, 2015.

COURTINE, Jean-Jacques; PIOVEZANI, Carlos (Org.). História da fala pública: uma arqueologia dos poderes do discurso. Petrópolis: Vozes, 2015

COURTINE, Jean-Jacques. A voz do povo: a fala pública, a multidão e as emoções na aurora da era das massas. In: . História da fala pública: uma arqueologia dos poderes do discurso. Petrópolis, Vozes, 2015. p.261-289.

DE CERTEAU, Michel; JULIA, Dominique; REVEL, Jacques. A beleza do morto: o conceito de cultura popular. In: REVEL, Jacques (Org.). A invenção da sociedade. Lisboa: Difel, 1989. p. 49-75.

DE CERTEAU, Michel. L'écriture de l'histoire. Paris: Gallimard, 2002.

FOUCAULT, Michel. A arqueologia do saber. Rio de Janeiro: Forense Universitária, 1997.

LEITE, Marli Quadros. Preconceito e intolerância na linguagem. São Paulo: Contexto, 2008.

PÊCHEUX, Michel. Semântica e discurso: uma crítica à afirmação do óbvio. Campinas: Editora da Unicamp, 1988.

PÊCHEUX, Michel. Delimitações, inversões, deslocamentos. Caderno de Estudos Linguísticos, v. 19, 1990.

PÊCHEUX, Michel. Análise automática do discurso. In: GADET, Françoise; HAK, Tony (Org.). Por uma análise automática do discurso. Campinas: Editora da Unicamp, 1997.

PEREIRA, Maísa Ramos. Do funcionamento discursivo dos pronunciamentos do presidente Lula a trabalhadores: procedimentos de legitimação do dizer político. Dissertação de Mestrado em Linguística pela Universidade Federal de São Carlos, 2013. 
EID\&A - Revista Eletrônica de Estudos Integrados em Discurso e Argumentação, Ilhéus, n. 16 esp. "Discurso e argumentação na política latino-americana, set.2018.

PIOVEZANI, Carlos. Falar em público na política contemporânea: a eloquência pop e popular brasileira na idade da mídia. In: . História da fala pública. Petrópolis: Vozes, 2015. p. 290-337.

PIOVEZANI, Carlos. Instantâneos de duradouros estigmas. Discursos sobre as vozes popular e feminina: da retórica antiga à mídia contemporânea. In: CURCINO, Luzmara et al. (Org.). (In)subordinações contemporâneas: consensos e resistências nos discursos. São Carlos: EdUFSCar, 2016. p.73-99.

POIZAT, Michel. Vox populi, vox Dei. Voix et pouvoir. Paris: Métailié, 2001.

QUINTILIANO. Institutions oratoires. Paris: Les Belles Lettres, 2003.

RANCIÈRE, Jacques. A noite dos proletários: arquivos do sonho operário. São Paulo: Companhia das Letras, 1988.

SALAZAR, Philippe-Joseph; PIOVEZANI, Carlos. A voz humana na era das redes sociais. Caderno de Estudos Linguísticos, v. 58, n. 1, 2016.

ZOPPI-FONTANA, Mónica. Cidadãos modernos: discurso e representação política. Campinas: Editora da Unicamp, 1997.

Forma de citação sugerida:

PIOVEZANI, Carlos. Política, mídia e fala popular. Um porta-voz do povo na imprensa brasileira. EID\&A - Revista Eletrônica de Estudos Integrados em Discurso e Argumentação, Ilhéus, n. 16 esp. "Discurso e argumentação na política latinoamericana", p. 52-70, set.2018. 